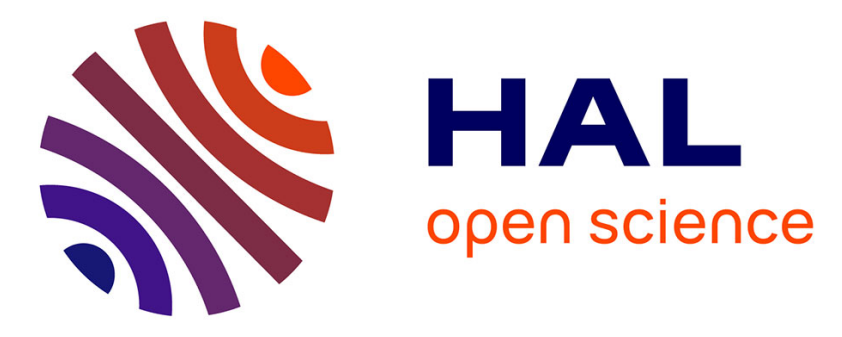

\title{
Small molecule inhibitors of peptidoglycan synthesis targeting the lipid II precursor
}

Adeline Derouaux, Samo Turk, Nick K. Olrichs, Stanislav Gobec, Eefjan Breukink, Ana Amoroso, Julien Offant, Julieanne Bostock, Katherine Mariner, Ian Chopra, et al.

\section{To cite this version:}

Adeline Derouaux, Samo Turk, Nick K. Olrichs, Stanislav Gobec, Eefjan Breukink, et al.. Small molecule inhibitors of peptidoglycan synthesis targeting the lipid II precursor. Biochemical Pharmacology, 2011, 81 (9), pp.1098. 10.1016/j.bcp.2011.02.008 . hal-00685076

\section{HAL Id: hal-00685076 https://hal.science/hal-00685076}

Submitted on 4 Apr 2012

HAL is a multi-disciplinary open access archive for the deposit and dissemination of scientific research documents, whether they are published or not. The documents may come from teaching and research institutions in France or abroad, or from public or private research centers.
L'archive ouverte pluridisciplinaire HAL, est destinée au dépôt et à la diffusion de documents scientifiques de niveau recherche, publiés ou non, émanant des établissements d'enseignement et de recherche français ou étrangers, des laboratoires publics ou privés. 


\section{Accepted Manuscript}

Title: Small molecule inhibitors of peptidoglycan synthesis targeting the lipid II precursor

Authors: Adeline Derouaux, Samo Turk, Nick K. Olrichs, Stanislav Gobec, Eefjan Breukink, Ana Amoroso, Julien Offant, Julieanne Bostock, Katherine Mariner, Ian Chopra,

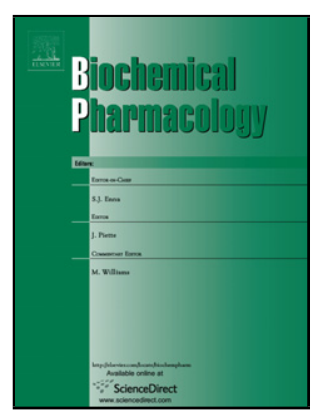
Thierry Vernet, Astrid Zervosen, Bernard Joris, Jean-Marie Frère, Martine Nguyen-Distèche, Mohammed Terrak

PII: S0006-2952(11)00112-2

DOI: doi:10.1016/j.bcp.2011.02.008

Reference: BCP 10829

To appear in: $B C P$

Received date: 21-12-2010

Revised date: $10-2-2011$

Accepted date: $14-2-2011$

Please cite this article as: Derouaux A, Turk S, Olrichs NK, Gobec S, Breukink E, Amoroso A, Offant J, Bostock J, Mariner K, Chopra I, Vernet T, Zervosen A, Joris B, Frère J-M, Nguyen-Distèche M, Terrak M, Small molecule inhibitors of peptidoglycan synthesis targeting the lipid II precursor, Biochemical Pharmacology (2010), doi:10.1016/j.bcp.2011.02.008

This is a PDF file of an unedited manuscript that has been accepted for publication. As a service to our customers we are providing this early version of the manuscript. The manuscript will undergo copyediting, typesetting, and review of the resulting proof before it is published in its final form. Please note that during the production process errors may be discovered which could affect the content, and all legal disclaimers that apply to the journal pertain. 
1 Small molecule inhibitors of peptidoglycan synthesis targeting the lipid II precursor

2 Running title: Small molecules targeting lipid II

3

4 Adeline Derouaux $^{\mathrm{a}}$, Samo Turk ${ }^{\mathrm{b}}$, Nick K. Olrichs ${ }^{\mathrm{c}}$, Stanislav Gobec ${ }^{\mathrm{b}}$, Eefjan Breukink ${ }^{\mathrm{c}}$, Ana

5 Amoroso $^{\mathrm{a}}$, Julien Offant ${ }^{\mathrm{d}}$, Julieanne Bostock ${ }^{\mathrm{e}}$, Katherine Mariner ${ }^{\mathrm{e}}$, Ian Chopra ${ }^{\mathrm{e}}$, Thierry

6 Vernet $^{\mathrm{d}}$, Astrid Zervosen ${ }^{\mathrm{f}}$, Bernard Joris ${ }^{\mathrm{a}}$, Jean-Marie Frère ${ }^{\mathrm{a}}$, Martine Nguyen-Distèche ${ }^{\mathrm{a}}$, and

$7 \quad$ Mohammed Terrak ${ }^{\mathrm{a}, *}$

8

9 a Centre d'Ingénierie des Protéines, Université de Liège, Allée de la chimie, B6a, B-4000, Sart

10 Tilman, Liège, Belgium.

$11{ }^{\mathrm{b}}$ University of Ljubljana, Faculty of Pharmacy, Aškerčeva 7, 1000 Ljubljana, Slovenia.

$12{ }^{\mathrm{c}}$ Department Biochemistry of Membranes, Bijvoet Center, Institute of Biomembranes,

13 Utrecht University, Utrecht $3584 \mathrm{CH}$, The Netherlands

14 dnstitut de Biologie Structurale (UMR 5075, Université Joseph Fourier, CNRS, CEA), Grenoble,

15 France

$16{ }^{\mathrm{e}}$ Institute of Molecular and Cellular Biology and Antimicrobial Research Centre, University 17 of Leeds, Leeds LS2 9JT, U.K.

$18{ }^{\mathrm{f}}$ Centre de Recherches du Cyclotron, Allée du 6 Août, 8, B30, Université de Liège, 4000 19 Liège, Belgium.

21 *Corresponding author: Mohammed Terrak, Centre d'Ingénierie des Protéines, Université 22 de Liège, Allée de la Chimie, B6a, B-4000, Sart Tilman, Liège, Belgium.

23 Tel.: 32-4-3663332; Fax: 32-4-3663364; E-mail: mterrak@ulg.ac.be. 


\section{Abstract}

2 Bacterial peptidoglycan glycosyltransferases (GTs) of family 51 catalyze the polymerization

3 of the lipid II precursor into linear peptidoglycan strands. This activity is essential to bacteria

4 and represents a validated target for the development of new antibacterials. Application of

5 structure-based virtual screening to the National Cancer Institute library using eHits program

6 and the structure of the glycosyltransferase domain of the Staphylococcus aureus penicillin-

7 binding protein 2 resulted in the identification of two small molecules analogues 5 , a 2-[1-[(2-

8 chlorophenyl)methyl]-2-methyl-5-methylsulfanylindol-3-yl]ethanamine and 5b, a 2-[1-[(3,4-

9 dichlorophenyl)methyl]-2-methyl-5-methylsulfanylindol-3-yl]ethanamine that exhibit

10 antibacterial activity against several Gram-positive bacteria but were less active on Gram-

11 negative bacteria. The two compounds inhibit the activity of five GTs in the micromolar

12 range. Investigation of the mechanism of action shows that the compounds specifically target

13 peptidoglycan synthesis. Unexpectedly, despite the fact that the compounds were predicted to

14 bind to the GT active site, compound $5 \mathrm{~b}$ was found to interact with the lipid II substrate via

15 the pyrophosphate motif. In addition, this compound showed a negatively charged

16 phospholipid-dependent membrane depolarization and disruption activity. These small

17 molecules are promising leads for the development of more active and specific compounds to 18 target the essential GT step in cell wall synthesis.

Keywords: Glycosyltransferase; Peptidoglycan; Antibacterial; Lipid II; Penicillin-Binding Protein. 


\section{Introduction}

The increase of bacterial resistance to antibiotics has resulted in a decline of available

efficient antibacterial treatments. Therefore, the discovery and development of new antibiotic classes able to cure infections due to resistant pathogens are urgently needed.

Peptidoglycan is an essential polymer and the main constituent of the bacterial cell

wall. Its biosynthesis requires several steps and offers many unexplored targets for the development of new antibacterial drugs $[1,2]$. The last two reactions in peptidoglycan

biosynthesis are performed by bifunctional penicillin-binding proteins (PBPs) and result in the assembly of the cell wall polymer from the monomeric intermediates [3]. This takes place outside the plasma membrane and relies on the activity of the glycosyltransferase (GT) module of bifunctional PBPs which uses the lipid II precursor to synthesize glycan chains and their transpeptidase module which catalyzes the cross-linking of two glycan chains via the peptide side chains. Inhibition of either of these two reactions leads to bacterial cell death. $\beta$ -

Lactam antibiotics target the transpeptidation reaction but antibiotic therapy based on inhibition of the GTs has not yet been developed. The only well characterized inhibitor targeting the GTs is the natural product moenomycin, a potent antibacterial phosphoglycolipid active at nanomolar concentrations [4]. Despite intensive studies of its structure-function properties it has not been developed for use in human chemotherapy because of poor pharmacokinetic properties related to its C25 lipid chain. A delipidated moenomycin is inactive and the sugar moiety can only be reduced to three saccharide units while retaining good antibacterial activity [4].

Recently the X-ray structures of PBPs or GT modules and their complexes with moenomycin A have been determined [5-8]. They shed light on the GT domain fold, which exhibits some similarities with that of $\lambda$-lysozyme and confirmed the catalytic mechanism of 
1 glycan chains elongation and the mode of action of moenomycin. The GT domain contains an

2 extended enzymatic cleft which can accommodate six sugar units. It is divided into two sub-

3 sites, a donor site for the elongating chain and an acceptor site for the lipid II substrate.

4 Between the sub-sites a flexible region is proposed to play an important role in the

5 translocation of the product from the acceptor site to the donor site through a folding and

6 unfolding process [9]. The enzymatic cavity is bordered by several conserved residues and

7 harbors the two glutamate residues essential for catalysis [10].

8 Inhibition of the GT reaction can be accomplished either by a compound binding to

9 the enzyme, like moenomycin which occupies the donor site mimicking the elongating glycan

10 chain [5], or by agent binding to the lipid II substrate [11]. Natural products such as nisin are

11 known to target the peptidoglycan precursor. Nisin binds to the pyrophosphate motif of lipid

12 II, sequestrates the substrate and induces pore formation in the bacterial membrane.

13 The potential of membrane damaging agents as antibacterials has been validated in the case of

14 the cyclic lipopeptide daptomycin, a drug used in the treatment of certain infections caused by

15 Gram-positive bacteria. Its antibacterial activity against Staphylococcus aureus including

16 methicillin-resistant strains has been shown to be the result of membrane potential disruption

$17 \quad[12]$

18 In this paper we report the discovery of new peptidoglycan GT inhibitors through the 19 use of structure-based virtual screening of small molecules from the National Cancer Institute 20 library. Selected hits were evaluated for their ability to inhibit in vitro the GTs activity of 21 Escherichia coli PBP1b in the presence of lipid II substrate, followed by the determination of 22 their effect on bacterial growth. The active compounds were then submitted to several assays 23 to demonstrate their specificities and modes of action. 


\section{MATERALS AND METHODS}

2

\subsection{Chemicals}

1,2-dioleoyl-sn-glycero-3-phosphocholine (DOPC), 1,2-dioleoyl-sn-glycero-3-[phospho-rac(1-glycerol)] (DOPG), 1,2-dioleoyl-sn-glycero-3-[phospho-rac-(3-lysyl(1-glycerol))] (lysylDOPG) and 1,2-dioleoyl-3-trimethylammonium-propane (DOTAP) were purchased from Avanti Polar Lipids Inc. Nisin A was produced, isolated, and purified as described [13].

Moenomycin A, was a gift from Aventis (France). The fluorescent dye 3,36-

diethylthiodicarbocyanine iodide $\left(\operatorname{DiSC}_{2}(5)\right)$ was from Molecular Probes Inc. Lipid I, Lipid II and Dansyl-lipid II were synthesized and purified as described elsewhere [14].

Undecaprenylphosphate and undecaprenylpyrophosphate were obtained by phosphorylation of undecaprenol [15] that was isolated from Laurus nobilis as described [16]. Radiolabeled $\left[{ }^{14} \mathrm{C}\right]$ meso-diaminopimelic acid $\left(\mathrm{A}_{2} \mathrm{pm}\right)$-labelled lipid II was prepared essentially as previously described [17].

The small molecules tested in this study were obtained from the National Cancer Institute and solubilised in DMSO at a concentration of $100 \mathrm{mM}$ or $10 \mathrm{mM}$ depending on the solubility of the compound. The identities of the active compounds 5 and $5 \mathrm{~b}\left(\mathrm{NSC}^{\circ} 17383\right.$, and $\mathrm{NSC} \mathrm{n}^{\circ}$ 17382 respectively) were verified by mass spectrometry and NMR. The data (not shown) were consistent with the expected mass and structure for both compounds.

\subsection{Proteins expression and purification}

Five model proteins of the GT51 family were prepared and used in this study. E. coli PBP1b, S. aureus MtgA and PBP2, and the PBP1a from Thermotoga maritima MSB8 were produced and purified as previously described [5, 17-19]. The gene encoding (A68-Q723) PBP2 of

Enterococcus hirae was cloned into pET28a (+) expression plasmid (Novagen) and the His 
1 Tag PBP2 was expressed in E. coli BL21 (DE3). The cells were grown at $37^{\circ} \mathrm{C}$ to an optical

2 density of 0.8 at $600 \mathrm{~nm}$, protein expression was induced with $0.5 \mathrm{mM}$ isopropyl $\beta-\mathrm{D}-1$ -

3 thiogalactopyranoside and incubation was continued overnight at $18^{\circ} \mathrm{C}$. The cells were

4 resuspended in $25 \mathrm{mM}$ HEPES $\mathrm{pH} 7.5,500 \mathrm{mM} \mathrm{NaCl}$ and the PBP2 was purified in one step

5 on a HisTrap column (GE, Heathcare) (unpublished results). The total protein yield was about

$615 \mathrm{mg}$ per litre of culture and the purity was over $90 \%$ as judged by on SDS-PAGE.

\subsection{Virtual screening}

The virtual screening was performed using the programme eHiTS 6.0 from SimBioSys Inc. eHiTS (http://www.simbiosys.com/ehits) [20,21] was used for the active site detection and docking. Open Babel (http://openbabel.org) was used for manipulating the ligands with various chemical formats. PyMol from DeLano Scientific was used for visual inspection of the results and the graphical representations.

The 3D structures of the compounds from the NCI Diversity Set were obtained from the NCI webpage (http://dtp.nci.nih.gov/dw/testmasters/chem3d.html). The 1990 highly diverse compounds of the NCI Diversity Set represented a broad chemical spectrum of the whole NCI database. However, no special preparation of the 3D structures was applied since eHiTS automatically evaluates all the possible protonation states for the ligands and enzymes. The crystal structure of $S$. aureus PBP2 as a complex with moenomycin (PDB entry 2OLV) [5] was initially prepared with eHiTS. The program automatically detected the ligand in the complex and selected the part of the enzyme within a $7 \AA$ margin around the ligand as the active site. The NCI Diversity Set was then docked into the active site. The scoring was according to the eHiTS_Score that is included in the eHiTS software package. Twodimensional similarities search was performed using a ZINC built-in engine and the entire NCI database containing more than 250000 compounds (Tanimoto similarity index was set to 
$10.75)$.

2 11 emission at $536 \mathrm{~nm}$.

12 For the other GT enzymes the reaction conditions were adapted for optimal activity as

\subsection{In vitro glycosyltransferase activity and GT inhibition assays}

\subsubsection{Fluorescence assay.}

GT activity was monitored using the continuous fluorescence assay method [22]. For the

simultaneous screening of numerous conditions this technique was adapted to a 96-well plate format (Greiner Bio-One). The standard reaction was carried out at $30^{\circ} \mathrm{C}$ in $50 \mu 1$ of $50 \mathrm{mM}$ Hepes pH 7.5, $200 \mathrm{mM} \mathrm{NaCl}, 0.2 \%$ decyl PEG, $10 \mathrm{mM} \mathrm{CaCl}_{2}, 20 \%$ DMSO, $10 \mu \mathrm{M}$ dansyllipid II, 1 unit of muramidase (Cellosyl) and $100 \mathrm{nM} \mathrm{E.} \mathrm{coli} \mathrm{PBP1b.} \mathrm{The} \mathrm{data} \mathrm{were} \mathrm{collected}$ for 30 min using a Victor 3 fluorimeter (Perkin Elmer) with excitation at $355 \mathrm{~nm}$ and follows, with only variable conditions given: $2 \mu \mathrm{M}$. aureus MtgA was used in the presence of $20 \mu \mathrm{M}$ dansyl-lipid II, 10\% DMSO and $10 \mathrm{mM} \mathrm{MnCl}_{2} .2 .5 \mu \mathrm{M}$ S. aureus PBP2 was used in the presence of $20 \mu \mathrm{M}$ dansyl-lipid II and $50 \mathrm{mM}$ sodium acetate $\mathrm{pH}$ 5. E. hirae PBP2 and T. maritima PBP1a were used at $300 \mathrm{nM}$ and $150 \mathrm{nM}$ respectively.

\subsubsection{Radioactive assay.}

The radioactive assay was performed in $30 \mu \mathrm{l}$ in the same conditions as the fluorescence assay using $4 \mu \mathrm{M}\left[{ }^{14} \mathrm{C}\right]$ lipid II $\left(0.126 \mu \mathrm{Ci} \mathrm{nmol}^{-1}\right)$ instead of the fluorescent substrate and by omitting the muramidase. The reaction was stopped with moenomycin $(10 \mu \mathrm{M})$ and the products were separated by TLC in 2-propanol-ammonium hydroxide- $\mathrm{H}_{2} \mathrm{O}(6: 3: 1 ; \mathrm{V} / \mathrm{V} / \mathrm{V})$ and analyzed using a Typhoon Trio+ Imager and the ImageQuant TL software (GE Healthcare).

\subsubsection{GT inhibition assay.}

The $\mathrm{IC}_{50}$ values of compounds 5 and $5 \mathrm{~b}$ were determined using a fluorescence based assay. 
1 The initial rate of the reaction was determined in the presence of various concentrations of

2 inhibitor (20-1500 $\mu \mathrm{M})$ and plotted versus the inhibitor concentration using the Sigma plot

3 program (Systas Software). The $\mathrm{IC}_{50}$ value is the inhibitor concentration that decreases the

$4 \quad$ initial rate by a factor of 2.

6 2.5. MIC determination and effect of $5 \mathrm{~b}$ on bacterial viability

7 The S. aureus, Enterococcus faecalis, Listeria innocua, Micrococcus luteus, Streptococcus

8 epidermis, Streptococcus pneumoniae and Pseudomonas aeruginosa strains listed in table 2

9 were obtained from the American Type Culture Collection (ATCC). The E. coli strains 1411 10 and SM 1411 were reported previously [23].

11 Minimum inhibitory concentration (MIC) determinations were carried out using the Clinical 12 and Laboratory Standard Institute (CLSI, 2009) broth microdilution method. Compounds 13 were solubilised in $100 \%$ DMSO at a concentration of $10 \mathrm{mg} / \mathrm{ml}$, and twenty-fold diluted in 14 Mueller-Hinton broth (MHB), just before utilization.

For bacterial viability experiments $S$. aureus ATCC 25923 colonies were grown overnight on Mueller-Hinton agar (MHA) plates and suspended in $\mathrm{MHB}\left(\cong 1.10^{8} \mathrm{CFU} / \mathrm{mL}\right)$. Compound 5b was added at 1,2 and 4 times the MIC and mixed. Samples were taken at different time intervals of incubation at $37^{\circ} \mathrm{C}$, serially diluted and plated on MHA in triplicate. The colonies were counted after incubation at $37^{\circ} \mathrm{C}$ for $18 \mathrm{~h}$.

\subsection{Pathway reporter assays in Bacillus subtilis}

We have employed a Bacillus subtilis reporter system which differentiates inhibitors of cell envelope, DNA, RNA, protein and fatty acid biosynthesis by quantifying the upregulation of a specific luciferase reporter construct in each case as described [24, 25].

The assay based on the LiaRS two-component system in Bacillus subtilis that senses 
1 stress on the cell wall caused by compounds interfering with lipid II cycle was used according

2 to published methods $[26,27]$. The $B$. subtilis strain BFS2470 carries a $\beta$-galactosidase

3 reporter gene under the control of liaI promoter. The effect of antibiotics or compounds

4 spotted on a Whatman disc is revealed by blue/white selection method after overnight

5 incubation at $37^{\circ} \mathrm{C}$ on agar-plate containing 5-bromo-4-chloro-3-indolyl-beta-D-

6 galactopyranoside (X-Gal). analysis according to Rouse et al. [30].

\subsection{Preparation of large unilamellar vesicles (LUVs)}

Large unilamellar vesicles were prepared essentially as described [28]. Desired amounts of lipid solutions in chloroform were mixed and evaporated under a gentle stream of nitrogen.

The lipid film was subsequently dried for 20 min under vacuum. The film was hydrated by the addition of the buffer of choice under mechanical agitation and submitted to ten freeze-thaw cycles using liquid nitrogen and a water bath. The lipid suspension was then extruded ten times through a polycarbonate membrane filter with a pore size of $200 \mathrm{~nm}$ (Whatman International) [29]. The final phospholipid concentration was determined by phosphate

\subsection{Vesicles binding assay}

DOPC with or without 1 mol\% Lipid II vesicles were prepared as described above in $10 \mathrm{mM}$ 
1 MES-KOH, $15 \mathrm{mM} \mathrm{K}_{2} \mathrm{SO}_{4}$ at $\mathrm{pH}$ 7. Vesicles (1 mM lipid Pi) were incubated with $5 \mu \mathrm{M}$ and

$220 \mu \mathrm{M} 5 \mathrm{~b}$, respectively, for $15 \mathrm{~min}$ at room temperature. The mixture was centrifuged in a

3 TLA 120.2 rotor using a Beckman Ultracentrifuge (TL-100) for $1.5 \mathrm{~h}$ at $100 \mathrm{krpm}$ and $20{ }^{\circ} \mathrm{C}$.

4 The amount of $5 \mathrm{~b}$ before centrifugation and in the supernatant and pellet was determined by

5 monitoring its intrinsic fluorescence on a Cary Eclipse fluorescence spectrophotometer

6 (Varian Inc.). The percentage of $5 \mathrm{~b}$ in the supernatant and pellet was determined by

7 comparing the maximal value $(350 \mathrm{~nm})$ of fluorescence emission intensity.

\subsection{Carboxyfluorescein leakage assay in large unilamellar vesicles}

Carboxyfluorescein (CF)-loaded LUVs were prepared in $50 \mathrm{mM} \mathrm{MES}-\mathrm{KOH}, 100 \mathrm{mM} \mathrm{K} \mathrm{SO}_{4}$, pH 6.5 (K+-buffer) as described above with the addition of $50 \mathrm{mM} \mathrm{CF}$. Following the extrusion step, the vesicle suspension was applied to Sephadex G-50 spin columns equilibrated with $\mathrm{K}+-$ buffer to remove free $\mathrm{CF}$. The final phospholipid concentration was determined by phosphate analysis according to Rouser et al. [30]. Vesicles were resuspended in $\mathrm{K}^{+}$-buffer to a concentration of $25 \mu \mathrm{M}$ and $5 \mathrm{~b}$ was added at the desired concentration $1 \mathrm{~min}$ prior to the addition of nisin $\mathrm{A}$ (50 nM, final conc.). High-salt experiments were conducted in $\mathrm{K}^{+}$-buffer supplemented with $0.5 \mathrm{M} \mathrm{NaCl}$. The nisin-induced $\mathrm{CF}$ leakage from the vesicles was monitored with excitation and emission wavelengths set at $430 \mathrm{~nm}$ and $513 \mathrm{~nm}$, respectively. Triton X-100 was added 1 min after the addition of nisin, to a final concentration of $0.2 \%(\mathrm{w} / \mathrm{v})$ to fully disrupt the lipid vesicles and the corresponding fluorescence was taken as $100 \%$ leakage. The $5 \mathrm{~b}$-induced reduction of leakage is expressed as a percentage of the 


\section{$1 \quad$ 2.11. Membrane depolarization assay}

2 The cytoplasmic membrane depolarization activity of $5 \mathrm{~b}$ was determined with the membrane

3 potential-sensitive dye $\operatorname{DiSC}_{2}(5)$ using Staphylococcus simulans and Micrococcus flavus

4 grown in $\mathrm{LB}$ broth at $37^{\circ} \mathrm{C}$ and $30^{\circ} \mathrm{C}$, respectively. Bacterial cells in the mid-logarithmic

5 phase were centrifuged at $5000 \mathrm{rpm}$, washed in $5 \mathrm{mM}$ HEPES (pH 7.8), and resuspended in

6 the same buffer to an optical density at $600 \mathrm{~nm}$ of 0.05 in a $1 \mathrm{~cm}$ cuvette. A stock solution of

$7 \quad \mathrm{DiSC}_{2}(5)$ was added to a final concentration of $0.4 \mu \mathrm{M}$ and quenching was allowed to occur at

8 room temperature for approximately $1 \mathrm{~min}$. The desired concentration of $5 \mathrm{~b}$ was added and

9 changes in fluorescence due to the disruption of the membrane potential gradient across the

10 cytoplasmic membrane were continuously recorded with a Cary Eclipse spectrofluorometer at 11 an excitation and emission wavelengths of 622 and $670 \mathrm{~nm}$, respectively.

12

13

14

15

16

17

18

\section{RESULTS}

\subsection{Structure-based virtual screening and identification of GT inhibitors hits}

We set out using a virtual screening approach based on the published S. aureus PBP2 structure in complex with moenomycin (PDB entry: 2OLV) [5] to identify small molecule inhibitors of the GT activity and to reduce the number of compounds to be tested using a direct in vitro assay based on lipid II substrate (see Materials and Methods). This approach has been used successfully in the identification of inhibitors of other targets of the cell wall synthesis pathway [31,32].

The selected compounds were first evaluated with $E$. coli PBP1b then with other GT including $S$. aureus PBP2 [5, 17]. In the first step of screening, the 30 highest ranked compounds (predicted pKd values between -3.61 and -4.37) were selected for biochemical 
1 testing. The number of compounds tested was further reduced to 21 as the remaining

2 compounds were insoluble. Soluble compounds were then tested in vitro at 0.2 and $1 \mathrm{mM}$

3 final concentrations for their ability to inhibit E. coli PBP1b GT activity in a 96-well

4 microtiter plate assay with fluorescent lipid II. Compounds which inhibited PBP1b activity or

5 interfered with the fluorescence assay were additionally tested in a radioactivity-based assay.

6 One compound (5, ranked as the fifth best by eHits) (Figure 1A), a 2-[1-[(2-

7 chlorophenyl)methyl]-2-methyl-5-methylsulfanylindol-3-yl]ethanamine, was found to inhibit

8 the GT activity of $E$. coli PBP1b ( $\mathrm{IC}_{50}$ of $\left.59 \mu \mathrm{M}\right)$. In the second step, a search based on two-

9 dimensional similarities to compound 5 identified an analogue of compound 5 called $5 b$

10 (Figure 1A), about 2 times more active than compound 5 against $E$. coli $\mathrm{PBP} 1 \mathrm{~b}\left(\mathrm{IC}_{50}\right.$ of 29

$11 \mu \mathrm{M})$ and was the focus of further characterisation.

12 The eHiTS-predicted binding mode of compound $5 \mathrm{~b}$ is presented in Figure 1B. The 13 model shows that compound 5b partly overlaps with co-crystallized moenomycin rings $\mathrm{C}$ and 14 E, but is buried deeper because of favourable hydrophobic interactions. On the other hand 15 moenomycin does not form hydrophobic interactions in the hydrophobic shelf due to its 16 hydrophilic character.

Interestingly, some indole derivatives were shown to inhibit lysozyme, a structural homologue of GT [33]. The docking model of indole 3-carbinol into the active site of lysozyme [34] shows some similarities with the predicted binding of compounds $5 / 5 \mathrm{~b}$ to the GT. Compounds $5 / 5 b$ at $1 \mathrm{mM}$ concentrations do not inhibit lysozyme and have no effect on the penicillin-binding activity of the second domain of E. coli PBP1b or the Actinomadura R39 DD-peptidase (data not shown). This indicates that compounds 5 and $5 \mathrm{~b}$ do not exhibit a promiscuous behaviour. Two other assays based on the use of a detergent $[35,36]$ and aggregation of the green fluorescent protein (GFP) [37] also support this observation (data not shown). 
1 3.2. Evaluation of compounds 5 and 5 b for GTs inhibition and antibacterial activity.

2 Both 5 and 5 b were able to inhibit the GT reaction catalyzed by the five GTs tested. The $\mathrm{IC}_{50}$

3 values of compound 5b for E. coli PBP1b, S. aureus PBP2 and MtgA, T. maritima PBP1a and

4 E. hirae PBP2 were determined using the fluorescence assay and were in the micromolar 5 range $(21-56 \mu \mathrm{M})$ (Table 1$)$.

Furthermore, both 5 and $5 \mathrm{~b}$ exhibit antibacterial activity against several important human Gram-positive pathogens with MIC values as low as $4 \mu \mathrm{g} / \mathrm{ml}$ (Table 2). Interestingly the compounds displayed MIC values of $4-8 \mu \mathrm{g} / \mathrm{ml}$ against methicillin-resistant $S$. aureus strains (MRSA) which pose a major problem in hospitals. The two GT inhibitors were less active against Gram-negative bacteria, as observed for other indole and tryptamine containing compounds [38-40]. The MIC values of compounds 5 and 5b against E. coli 1411 were 64 and $16 \mu \mathrm{g} / \mathrm{ml}$ respectively. They decreased to the values observed in Gram-positive organisms after polymyxin B nonapeptide (PMBN) treatment, or in an acrAB efflux mutant (Table 2). These data suggest that uptake of the compounds into E. coli is affected both by efflux and poor permeation through the outer membrane.

The effect of different concentrations of compound $5 \mathrm{~b}$ on the growth and survival of $S$. aureus was evaluated by measuring the number of living cells and turbidity over time. The killing curves at $1 \mathrm{x}$ MIC $(10 \mu \mathrm{M})$ and $2 \mathrm{x}$ MIC show that $5 \mathrm{~b}$ causes an approximately $1 \log _{10}$ and $1.3 \log _{10}$ reduction of viability respectively after $90 \mathrm{~min}$ (Figure 2). At time zero (during sample mixing) the cell count was slightly lower than the control. At 4x MIC, the killing curve shows that $5 \mathrm{~b}$ causes an immediate decrease in the bacterial count, more important than that observed at $1 \mathrm{x}$ and $2 \mathrm{x}$ MIC (1x $\log _{10}$ approximately), followed by a slower phase yielding an approximately $5.4 \log 10$ reduction of viability after 90 minutes (Figure 2) and no viable cells were observed after 120 min (data not shown) showing that the compound is bactericidal. Similarly, the cell turbidity (Absorbance at 600nm) at $4 \mathrm{x}$ MIC also decreased 
$1(36 \%)$ immediately after addition of $5 b$, then remained unchanged (data not shown). It seems

2 that a two-phase process is taking place upon addition of $5 \mathrm{~b}$ to the cells: a rapid phase occurs

3 immediately after addition of the compound followed by a slower one.

\section{$5 \quad$ 3.3. Mode of action of compounds 5 and $5 b$}

$6 \quad$ 3.3.1. Compounds 5 and 5 b induce cell wall biosensors in Bacillus subtilis.

7 Compounds 5 and $5 \mathrm{~b}$ were predicted to specifically target peptidoglycan synthesis in bacterial

8 cells. In order to characterize their mode of action we have employed a Bacillus subtilis

9 reporter assay which differentiates inhibitors of cell wall, DNA, RNA, protein and fatty acid biosynthesis by quantifying the upregulation of specific luciferase reporter gene constructs in each pathway $[24,25]$. Using this system, only the cell wall biosensor expression was induced in the presence of compounds 5 and $5 \mathrm{~b}$ showing that they specifically inhibit cell wall biosynthesis as initially hypothesised (Table 3).

Two possible mechanisms for inhibition of the GT reaction include direct binding to the enzyme, or binding to the lipid II substrate. Experiments using fluorescence and microcalorimetry were not conclusive on whether $5 b$ binds a GT enzyme (data not shown). Therefore, we checked whether 5 and $5 \mathrm{~b}$ could interfere with the lipid II. First we used the Bacillus subtilis reporter strain BFS2470 ( $\beta$-galactosidase reporter system) sensing cell wall antibiotics that interfere with the lipid II cycle [26, 27]. Using a disk diffusion assay with different antibiotics or compounds 5 or $5 b$ on agar-plates containing X-Gal, the following observations were made (Figure 3A): compounds 5, 5b and nisin (as a positive control) produced a blue colour at the edge of the inhibition halo indicating an interaction of compounds 5 and $5 \mathrm{~b}$ with the lipid II. In contrast, moenomycin and ampicillin did not induce $\beta$-galactosidase and the blue colour around the inhibition zone. These results indicate that compounds 5 and 5 b could interact with lipid II. 
$1 \quad$ 3.3.2. Compound 5 b interacts with lipid II.

2 To test for a possible specific interaction between $5 \mathrm{~b}$ and lipid II, a competition assay was set

3 up with the lantibiotic nisin, which uses lipid II for its pore-forming activity [14, 41, 42]. This

4 experiment was performed with compound $5 \mathrm{~b}$ which is more active than 5 on GT activity. A

5 similar approach had previously been used with vancomycin in the study that determined the

6 inhibition of the lipid II-dependent pore-forming activity of nisin by vancomycin in intact

7 cells [43] and in a model membrane setup as is used here (data not shown) [44]. The addition

8 of nisin to carboxyfluorescein-loaded vesicles containing lipid II causes leakage of the

9 fluorescent dye from the vesicles, due to lipid II-dependent pore formation by nisin (CF 10 loaded vesicles without lipid II showed negligible leakage after adding nisin, Figure 4). When $1150 \mathrm{nM}$ nisin was added to $25 \mu \mathrm{M}$ DOPC vesicles containing $0.1 \mathrm{~mol} \%$ lipid II, a leakage of $12 \sim 75 \%$ was observed. In the presence of $2.5 \mu \mathrm{M} 5 \mathrm{~b}$, CF leakage was significantly decreased by $13 \sim 36 \%$. Moreover, increasing concentrations of $5 \mathrm{~b}$ resulted in higher reductions and almost 14 complete inhibition of leakage at $15 \mu \mathrm{M}(1.5 \mathrm{x}$ MIC) (Figure 3B). These results suggest that $155 \mathrm{~b}$ binds to lipid II, thereby preventing an interaction of the latter with nisin.

16 To get insight into the binding site of $5 \mathrm{~b}$ on lipid II, we first tested whether $5 \mathrm{~b}$ could 17 also inhibit the lipid I-dependent pore-forming activity of nisin. Nisin does not discriminate 18 between lipid I (lacking the GlcNAc moiety) and lipid II. Leakage due to pore formation of 19 nisin with lipid I was diminished to an equal extent by the presence of $5 \mathrm{~b}$ as with lipid II (data 20 not shown). This suggests that the GlcNAc moiety of lipid II is not an essential requirement 21 for the interaction. If $5 \mathrm{~b}$ specifically interacts with lipid II, structurally related compounds 22 should compete for binding. In order to test possible interaction of $5 b$ with the 23 (pyro)phosphate moiety of lipid II, the inhibition effect of $5 b$ on nisin-lipid II pore formation 24 was analyzed in the presence of the peptidoglycan biosynthetic intermediates 25 undecaprenylphosphate (11-P) or undecaprenylpyrophosphate (11-PP), respectively (Figure 
$13 \mathrm{C})$. Nisin activity in the presence and absence of $5 \mathrm{~b}$ was analyzed in CF-loaded DOPC

2 vesicles containing $0.1 \mathrm{~mol} \%$ lipid II and $2 \mathrm{~mol} \%$ of either 11-P, 11-PP or, as a control, the

3 anionic lipid DOPG. Strikingly, in the 11-PP containing vesicles, nisin induced CF-release

4 was not significantly reduced in the presence of $2.5 \mu \mathrm{M} 5 \mathrm{~b}$. In comparison, $5 \mathrm{~b}$ was still able to

5 cause significant inhibition of nisin activity in the presence of 11-P or DOPG, albeit

6 somewhat less profound than in their absence (Figure 3C). This indicates that the excess of

7 11-PP competes with lipid II for binding $5 \mathrm{~b}$ and that the pyrophosphate moiety is important

8 for the interaction. To investigate this in more detail, NMR measurements were performed

9 using undecaprenylpyrophosphate in detergent micelles in the presence and absence of $5 \mathrm{~b} .{ }^{31} \mathrm{P}$

\subsubsection{Membrane disruptive effects of $5 b$}

The vesicle binding assay using ultracentrifugation showed that $5 \mathrm{~b}$ was present exclusively in the pellet in both lipid II-containing and pure DOPC large unilamellar vesicles (LUVs) while $5 \mathrm{~b}$ alone was present in the supernatant (data not shown). This shows that $5 \mathrm{~b}$ has an affinity for the lipid vesicles, regardless of whether lipid II is present or not. To gain insight into the effect of $5 b$ on membrane, leakage experiments were subsequently conducted with LUVs containing anionic phospholipids in the absence of lipid II. Vesicles composed of only the zwitterionic lipid DOPC displayed negligible leakage even in the presence of $40 \mu \mathrm{M} 5 \mathrm{~b}$ (Figure 4A). Strikingly, in the presence of the negatively charged phospholipid DOPG leakage was detected at $5 \mu \mathrm{M}$ concentration and almost total CF-leakage was obtained at 20 $\mu \mathrm{M}$ of $5 \mathrm{~b}$ (Figure $4 \mathrm{~A}$ ). This suggests that $5 \mathrm{~b}$ has a general membrane effect independent of 
1 lipid II, and this disruption of membrane integrity is anionic lipid-dependent.

2 To investigate if $5 \mathrm{~b}$ exerts similar effects on bacterial membranes that are known to 3 contain relatively large amounts of negatively charged lipids, the depolarization effect of $5 \mathrm{~b}$

4 on the plasma membrane in intact cells of Staphylococcus simulans and Micrococcus flavus

5 was determined using the membrane-potential sensitive fluorophore $\operatorname{DiSC}_{2}(5)$. This dye

6 inserts into the cytoplasmic membrane in the presence of a membrane potential resulting in

7 self-quenching of fluorescence. The addition of $5 \mathrm{~b}$ to a final concentration of $1 \mu \mathrm{M}$ caused a

8 major release of the dye from the membrane in $M$. flavus (Figure $4 \mathrm{~b}$ ) showing that the

9 membrane potential was dissipated upon binding of 5b. S. simulans also showed significant

membrane depolarization at $5 \mu \mathrm{M}$ concentration of $5 \mathrm{~b}$. Nisin was more effective in dissipating

11 the membrane potential in M. flavus (Figure 4b), which is in relative agreement with the 12 difference in MIC values for both compounds ( $\sim \mathrm{nM}$ nisin for $M$. flavus versus $\sim 10 \mu \mathrm{M} 5 \mathrm{~b}$ 13 for most Gram-positive strains tested).

14 These results are supported by experiments performed with the LIVE/DEAD

15 BacLight ${ }^{\mathrm{TM}}$ bacterial viability assay [45]. The membrane damage inflicted by a 10 minute

16 exposure to compound $5 \mathrm{~b}$ on $S$. aureus was analysed. Cells treated with the test agent $5 \mathrm{~b}$ at $4 \mathrm{x}$

17 MIC only maintained 33\% membrane integrity (67\% damage), which does suggest that the 18 membranes of $S$. aureus cells were permeabilized by the addition of $5 \mathrm{~b}$.

\section{DISCUSSION}

Peptidoglycan assemblage can be efficiently disrupted either through the inhibition of the glycosyltransferase or the transpeptidase enzymatic activities or by sequestration of the lipid II, thus, preventing its use as a substrate.

In our effort to identify small molecules inhibitors of the GT reaction, we have 
1 discovered two structurally related indole derivative compounds (5 and 5b) inhibiting several

2 GTs in vitro and having good antibacterial activity in the micromolar range. These

3 compounds specifically induce peptidoglycan pathway stress sensors in Bacillus, confirming

4 that bacterial cell wall synthesis is the target.

Moreover, we have found that compound $5 \mathrm{~b}$ binds to the lipid II precursor. This is

6 reminiscent of several lipid II-targeting antibiotics such as vancomycin and related (second

7 generation) glycopeptides [46], and the lantibiotics mersacidin and nisin [11].

8 Undecaprenylpyrophosphate competes with lipid II for interaction with 5b. As

9 undecaprenylphosphate and DOPG did not significantly compete with lipid II for $5 \mathrm{~b}$, the

10 pyrophosphate moiety appears to be essential for the interaction with $5 \mathrm{~b}$. Nisin also binds the

11 pyrophosphate of lipid II, and this could explain the effective inhibition of nisin-lipid II pore

12 assembly by $5 \mathrm{~b}$. The data obtained from NMR analysis of undecaprenylpyrophosphate in the 13 presence and absence of $5 \mathrm{~b}$ further strengthens the hypothesis that the pyrophosphate moiety 14 is critical for complex formation of $5 b$ with lipid II. The amine residue of $5 b$ has 15 independently been shown to be essential for its glycosyltransferase inhibiting activity, 16 suggesting its crucial involvement in the interaction with the pyrophosphate group of lipid II. 17 The bacitracin antibiotic has also been shown to inhibit PG synthesis by sequestration of 18 undecaprenyl pyrophosphate and was known to specifically bind to the pyrophosphate moiety 19 of the lipid carrier [47].

20 Compound $5 \mathrm{~b}$ at low concentration caused membrane depolarization in $M$. flavus and 21 S. simulans as did nisin. Several lines of evidence also indicate that compound $5 \mathrm{~b}$ affects in 22 vitro membrane integrity in a negatively charged lipid dependent way in the absence of lipid 23 II. These results suggest that membrane disruption could contribute to its antibacterial 24 activity. Indeed, the effect of $5 \mathrm{~b}$ on $S$. aureus viability shows that a two phase process 25 contributes to its bactericidal activity. The first and immediate effect could be the result of 
1 membrane integrity disruption. The second and slower phase (4x MIC) is more likely the

2 consequence of cell wall synthesis inhibition as was previously observed for the kinetics of

3 inhibition of $S$. aureus by moenomycin [48]. Therefore, it appears from our data that the

4 identified compounds have two modes of action, namely, inhibition of cell wall synthesis and

5 membrane depolarization/disruption. This mode of action resembles that of nisin which binds

6 and sequesters lipid II preventing its use by the peptidoglycan polymerases and inducing

7 pores formation in the bacterial membrane and membrane depolarization. The properties

8 described for 5 b could also be shared by compound 5 due to close similarity between the two

9 compounds.

Bacterial resistance to antibiotics requires a continuing effort to find new antibacterial

11 compounds able to cope with emerging resistant strains. The glycosyltransferase step in

12 peptidoglycan biosynthesis is a validated target for new antibacterial development. The small

13 antibacterial molecules described here are much simpler agents compared to known natural

14 products targeting lipid II. Considering the importance of lipid II and the pyrophosphate

15 motif for the whole enzymatic machinery of the bacterial cell wall synthesis pathway, this

16 simple mode of binding to lipid II may limit the occurrence of resistance to such promising

17 compounds. Finally, this work provides the basis for the development of more active and

18 specific analogues of compounds $5 / 5 \mathrm{~b}$ to target the essential GT step in cell wall synthesis

19 using small molecule inhibitors.

\section{Acknowledgments}

22 This work was supported by the European Commission within the "EUR-INTAFAR"

23 (Inhibition of New Targets for Fighting Antibiotic Resistance) (LSHM-CT-2004-512138)

24 network, and the Fonds de la Recherche Fondamentale Collective (FRFC n ${ }^{\circ} 2.4506 .08$ and n $^{\circ}$

25 2.4511.06). MT is a Research Associate of the National Fond for Scientific Research 
1 (F.R.S_FNRS, Belgium). We thank the National Cancer Institute for providing the

2 compounds and SimBioSys Inc. for free academic license for eHiTS 6.0. We thank John

3 Helmann for supplying bacteria and Waldemar Vollmer for critical reading of the manuscript.

4 We thank Jennifer Griffiths and Marie Schloesser for technical assistance.

\section{REFERENCES}

8 1. Barreteau H, Kovac A, Boniface A, Sova M, Gobec S and Blanot D, Cytoplasmic steps of peptidoglycan biosynthesis. FEMS Microbiol Rev 32(2): 168-207, 2008.

2. Bouhss A, Trunkfield AE, Bugg TD and Mengin-Lecreulx D, The biosynthesis of peptidoglycan lipid-linked intermediates. FEMS Microbiol Rev 32(2): 208-33, 2008.

3. Sauvage E, Kerff F, Terrak M, Ayala JA and Charlier P, The penicillin-binding proteins: structure and role in peptidoglycan biosynthesis. FEMS Microbiol Rev 32(2): 234-58, 2008.

4. Welzel P, Syntheses around the transglycosylation step in peptidoglycan biosynthesis. Chem Rev 105(12): 4610-60, 2005.

5. Lovering AL, de Castro LH, Lim D and Strynadka NC, Structural insight into the transglycosylation step of bacterial cell-wall biosynthesis. Science 315(5817): 1402-5, 2007.

6. Yuan Y, Fuse S, Ostash B, Sliz P, Kahne D and Walker S, Structural analysis of the contacts anchoring moenomycin to peptidoglycan glycosyltransferases and implications for antibiotic design. ACS Chem Biol 3(7): 429-36, 2008.

7. Sung MT, Lai YT, Huang CY, Chou LY, Shih HW, Cheng WC, Wong CH and Ma C, Crystal structure of the membrane-bound bifunctional transglycosylase PBP1b from Escherichia coli. Proc Natl Acad Sci U S A 106(22): 8824-9, 2009. 
8. Heaslet H, Shaw B, Mistry A and Miller AA, Characterization of the active site of Staphylococcus aureus monofunctional glycosyltransferase (Mtg) by site-directed mutation and structural analysis of the protein complexed with moenomycin. J Struct Biol 167(2): 129-35, 2009.

9. Lovering AL, De Castro L and Strynadka NC, Identification of dynamic structural motifs involved in peptidoglycan glycosyltransfer. J Mol Biol 383(1): 167-77, 2008.

10. Terrak M, Sauvage E, Derouaux A, Dehareng D, Bouhss A, Breukink E, Jeanjean S and Nguyen-Disteche M, Importance of the Conserved Residues in the Peptidoglycan Glycosyltransferase Module of the Class A Penicillin-binding Protein 1b of Escherichia coli. J Biol Chem 283(42): 28464-28470, 2008.

11 11. Breukink E and de Kruijff B, Lipid II as a target for antibiotics. Nat Rev Drug Discov 5(4): 321-32, 2006.

12. Silverman JA, Perlmutter NG and Shapiro HM, Correlation of daptomycin bactericidal activity and membrane depolarization in Staphylococcus aureus. Antimicrob Agents Chemother 47(8): 2538-44, 2003.

13. Kuipers OP, Rollema HS, Yap WM, Boot HJ, Siezen RJ and de Vos WM, Engineering dehydrated amino acid residues in the antimicrobial peptide nisin. $J$ Biol Chem 267(34): 24340-6, 1992.

14. Breukink E, van Heusden HE, Vollmerhaus PJ, Swiezewska E, Brunner L, Walker S, Heck AJ and de Kruijff B, Lipid II is an intrinsic component of the pore induced by nisin in bacterial membranes. J Biol Chem 278(22): 19898-903, 2003.

15. Danilov LL, Druzhinina TN, Kalinchuk NA, Maltsev SD and Shibaev VN, Polyprenyl phosphates: synthesis and structure-activity relationship for a biosynthetic system of Salmonella anatum O-specific polysaccharide. Chem Phys Lipids 51(3-4): 191-203, 1989. 
1 16. Swiezewska E, Sasak W, Mankowski T, Jankowski W, Vogtman T, Krajewska I, Hertel J, Skoczylas E and Chojnacki T, The search for plant polyprenols. Acta Biochim Pol 41(3): 221-60, 1994.

17. Terrak M, Ghosh TK, van Heijenoort J, Van Beeumen J, Lampilas M, Aszodi J, Ayala JA, Ghuysen JM and Nguyen-Distèche M, The catalytic, glycosyl transferase and acyl transferase modules of the cell wall peptidoglycan-polymerizing penicillin-binding protein 1b of Escherichia coli. Mol Microbiol 34(2): 350-64, 1999.

18. Terrak M and Nguyen-Distèche M, Kinetic characterization of the monofunctional glycosyltransferase from Staphylococcus aureus. J Bacteriol 188(7): 2528-32, 2006.

19. Offant J, Terrak M, Derouaux A, Breukink E, Nguyen-Disteche M, Zapun A and Vernet T, Optimization of conditions for the glycosyltransferase activity of penicillinbinding protein 1a from Thermotoga maritima. Febs $J$ 277(20): 4290-8.

20. Zsoldos Z, Reid D, Simon A, Sadjad BS and Johnson AP, eHiTS: an innovative approach to the docking and scoring function problems. Curr Protein Pept Sci 7(5): 421-35, 2006.

21. Zsoldos Z, Reid D, Simon A, Sadjad SB and Johnson AP, eHiTS: a new fast, exhaustive flexible ligand docking system. J Mol Graph Model 26(1): 198-212, 2007.

22. Schwartz B, Markwalder JA, Seitz SP, Wang Y and Stein RL, A kinetic characterization of the glycosyltransferase activity of Eschericia coli PBP1b and development of a continuous fluorescence assay. Biochemistry 41(41): 12552-61, 2002.

23. O'Neill AJ, Bostock JM, Moita AM and Chopra I, Antimicrobial activity and mechanisms of resistance to cephalosporin P1, an antibiotic related to fusidic acid. $J$ Antimicrob Chemother 50(6): 839-48, 2002.

24. Urban A, Eckermann S, Fast B, Metzger S, Gehling M, Ziegelbauer K, Rubsamen- 
Waigmann $\mathrm{H}$ and Freiberg $\mathrm{C}$, Novel whole-cell antibiotic biosensors for compound discovery. Appl Environ Microbiol 73(20): 6436-43, 2007.

25. Mariner KR, Trowbridge R, Agarwal AK, Miller K, O'Neill AJ, Fishwick CW and Chopra I, Furanyl-rhodanines are unattractive drug candidates for development as inhibitors of bacterial RNA polymerase. Antimicrob Agents Chemother 54(10): 45069, 2010.

26. Mascher T, Zimmer SL, Smith TA and Helmann JD, Antibiotic-inducible promoter regulated by the cell envelope stress-sensing two-component system LiaRS of Bacillus subtilis. Antimicrob Agents Chemother 48(8): 2888-96, 2004.

27. Burkard M and Stein T, Microtiter plate bioassay to monitor the interference of antibiotics with the lipid II cycle essential for peptidoglycan biosynthesis. J Microbiol Methods 75(1): 70-4, 2008.

28. Breukink E, van Kraaij C, Demel RA, Siezen RJ, Kuipers OP and de Kruijff B, The Cterminal region of nisin is responsible for the initial interaction of nisin with the target membrane. Biochemistry 36(23): 6968-76, 1997.

29. Hope MJ, Bally MB, Webb G and Cullis PR, Production of large unilamellar vesicles by a rapid extrusion procedure. Characterization of size distribution, trapped volume and ability to maintain a membrane potential. Biochimica et Biophysica Acta 812: 55$65,1985$.

30. Rouser G, Fkeischer S and Yamamoto A, Two dimensional then layer chromatographic separation of polar lipids and determination of phospholipids by phosphorus analysis of spots. Lipids 5(5): 494-6, 1970.

31. Kovac A, Konc J, Vehar B, Bostock JM, Chopra I, Janezic D and Gobec S, Discovery of new inhibitors of D-alanine:D-alanine ligase by structure-based virtual screening. $J$ Med Chem 51(23): 7442-8, 2008. 
1 32. Turk S, Kovac A, Boniface A, Bostock JM, Chopra I, Blanot D and Gobec S, Discovery of new inhibitors of the bacterial peptidoglycan biosynthesis enzymes MurD and MurF by structure-based virtual screening. Bioorg Med Chem 17(5): 18849, 2009.

33. Swan ID, The inhibition of hen egg-white lysozyme by imidazole and indole derivatives. J Mol Biol 65(1): 59-62, 1972.

34. Morshedi D, Rezaei-Ghaleh N, Ebrahim-Habibi A, Ahmadian S and Nemat-Gorgani M, Inhibition of amyloid fibrillation of lysozyme by indole derivatives--possible mechanism of action. Febs $J$ 274(24): 6415-25, 2007.

35. Jadhav A, Ferreira RS, Klumpp C, Mott BT, Austin CP, Inglese J, Thomas CJ, Maloney DJ, Shoichet BK and Simeonov A, Quantitative analyses of aggregation, autofluorescence, and reactivity artifacts in a screen for inhibitors of a thiol protease. $J$ Med Chem 53(1): 37-51, 2009.

36. Feng BY and Shoichet BK, A detergent-based assay for the detection of promiscuous inhibitors. Nat Protoc 1(2): 550-3, 2006.

37. McGovern SL, Helfand BT, Feng B and Shoichet BK, A specific mechanism of nonspecific inhibition. J Med Chem 46(20): 4265-72, 2003.

38. Huber J, Donald RG, Lee SH, Jarantow LW, Salvatore MJ, Meng X, Painter R, Onishi RH, Occi J, Dorso K, Young K, Park YW, Skwish S, Szymonifka MJ, Waddell TS, Miesel L, Phillips JW and Roemer T, Chemical genetic identification of peptidoglycan inhibitors potentiating carbapenem activity against methicillin-resistant Staphylococcus aureus. Chem Biol 16(8): 837-48, 2009.

39. Lee NK, Fenical W and Lindquist N, Alternatamides A-D: new bromotryptamine peptide antibiotics from the Atlantic marine bryozoan Amathia alternata. J Nat Prod 60(7): 697-9, 1997. 
1 40. Yamamoto Y and Kurazono M, A new class of anti-MRSA and anti-VRE agents: preparation and antibacterial activities of indole-containing compounds. Bioorg Med Chem Lett 17(6): 1626-8, 2007.

41. van Heusden HE, de Kruijff B and Breukink E, Lipid II induces a transmembrane orientation of the pore-forming peptide lantibiotic nisin. Biochemistry 41(40): 121718, 2002.

42. Wiedemann I, Breukink E, van Kraaij C, Kuipers OP, Bierbaum G, de Kruijff B and Sahl HG, Specific binding of nisin to the peptidoglycan precursor lipid II combines pore formation and inhibition of cell wall biosynthesis for potent antibiotic activity. $J$ Biol Chem 276(3): 1772-9, 2001.

43. Breukink E, Wiedemann I, van Kraaij C, Kuipers OP, Sahl H and de Kruijff B, Use of the cell wall precursor lipid II by a pore-forming peptide antibiotic. Science 286(5448): 2361-4, 1999.

44. Vollmerhaus PJ, Breukink E and Heck AJ, Getting closer to the real bacterial cell wall target: biomolecular interactions of water-soluble lipid II with glycopeptide antibiotics. Chemistry 9(7): 1556-65, 2003.

45. Hilliard JJ, Goldschmidt RM, Licata L, Baum EZ and Bush K, Multiple mechanisms of action for inhibitors of histidine protein kinases from bacterial two-component systems. Antimicrob Agents Chemother 43(7): 1693-9, 1999.

46. Leadbetter MR, Adams SM, Bazzini B, Fatheree PR, Karr DE, Krause KM, Lam BM, Linsell MS, Nodwell MB, Pace JL, Quast K, Shaw JP, Soriano E, Trapp SG, Villena JD, Wu TX, Christensen BG and Judice JK, Hydrophobic vancomycin derivatives with improved ADME properties: discovery of telavancin (TD-6424). J Antibiot (Tokyo) 57(5): 326-36, 2004.

47. Storm DR and Strominger JL, Complex formation between bacitracin peptides and 
isoprenyl pyrophosphates. The specificity of lipid-peptide interactions. J Biol Chem

1 248(11): 3940-5, 1973.

48. Baizman ER, Branstrom AA, Longley CB, Allanson N, Sofia MJ, Gange D and Goldman RC, Antibacterial activity of synthetic analogues based on the disaccharide structure of moenomycin, an inhibitor of bacterial transglycosylase. Microbiology 146 Pt 12: 3129-40, 2000. 


\section{$1 \quad$ Figure legends}

\section{Figure 1. Structures of the compounds 5 and $5 \mathrm{~b}$ and the predicted binding model of} compound 5b to S. aureus PBP2 active site. A. Structures of the compounds 5, 2-[1-[(2-

chlorophenyl)methyl]-2-methyl-5-methylsulfanylindol-3-yl]ethanamine and 5b, 2-[1-[(3,4dichlorophenyl)methyl]-2-methyl-5-methylsulfanylindol-3-yl]ethanamine. B.

Superimposition of the computer model of compound $5 \mathrm{~b}$ (blue) on the X-ray structure of moenomycin (magenta lines, moenomycin rings are labeled from A to F) bound to S. aureus PBP2 (pdb code: 2OLV). Amino acids that interact with compound $5 \mathrm{~b}$ are presented as sticks. Hydrophobic residues are shown as semi-transparent yellow surfaces. Hydrogen bonds between the free amino group of compound $5 \mathrm{~b}$ and the Asp156 side chain are represented as dotted lines.

Figure 2. Effect of compound $5 b$ on bacterial viability.

Cell viability after exposure of $S$. aureus ATCC 25923 to 1,2 , and 4 times the MIC of compound $5 b$.

\section{Figure 3. Interaction of compound 5 and $5 b$ with lipid II.}

A. Effect of compounds 5, 5b and control agents on the lipid II cycle. The control antibiotics or compounds were spotted at the indicated amount on a Whatman disc on an agar-plate containing X-Gal and inoculated with the Bacillus subtilis strain BFS2470. The picture was taken after overnight incubation at $37^{\circ} \mathrm{C}$.

B. Effect of $5 \mathrm{~b}$ on nisin pore formation in DOPC LUVs containing $0.1 \mathrm{~mol} \%$ lipid II.

Compound $5 \mathrm{~b}$ reduced the leakage of carboxyfluorescein induced by nisin.

C. Competition of undecaprenylpyrophosphate (11-PP), undecaprenylphosphate (11-P) and 
1 DOPG with lipid II (LII) (20 fold molar access over lipid II) for $5 \mathrm{~b}(2.5 \mu \mathrm{M})$ binding. The

2 averages of two independent experiments are shown with the error bars indicating the spread

3 between values. Experiments were also conducted in the absence of $5 \mathrm{~b}$ as the leakage

4 reduction is depicted as a percentage of the leakage without $5 \mathrm{~b}$ (the latter was similar in all

5 three cases).

6 D. ${ }^{31} \mathrm{P}-\mathrm{NMR}$ of undecaprenylpyrophosphate in Triton-X100 micelles in the presence or 7 absence of $1 \mathrm{mM} 5 \mathrm{~b}$.

9 Figure 4. Membrane disruption effect of compound $5 \mathbf{b}$.

10 A. Comparison of the disruptive effect of compound $\mathbf{5 b}$ on DOPC/DOPG (1:1 $\mathrm{mol} / \mathrm{mol})$ and 11 DOPC vesicles.

12 B. Effect of 5b on the plasma membrane potential of Staphylococcus simulans and 13 Micrococcus flavus using $\mathrm{DiSC}_{2}(5)$. Dye release was monitored at excitation and emission 14 wavelengths of 622 and $670 \mathrm{~nm}$, respectively.

List of abbreviations

PBP: penicillin-binding protein

19 GT: glycosyltransferase

20 PG: peptidoglycan

21 CF: carboxyfluorescein

22 DOPC: 1,2-Dioleoyl-sn-glycero-3-phosphocholine

23 DOPG: 1,2-dioleoyl-sn-glycero-3-[phospho-rac-(1-glycerol)]

24 11-PP: undecaprenylpyrophosphate

25 11-P: undecaprenylphosphate

26 LUV: large unilamellar vesicle 
Table 1. $\mathrm{IC}_{50}$ values of compound $5 \mathrm{~b}$ for various GTs.

\begin{tabular}{lc}
\hline \multicolumn{2}{c}{$\mathrm{IC}_{50}(\mu \mathrm{M})$} \\
\hline E. coli PBP1b & Compound 5b \\
S. aureus PBP2 & $29 \pm 12$ \\
T. maritima PBP1a & $20.7 \pm 1$ \\
E. hirae PBP2 & $56 \pm 7$ \\
S. aureus MtgA & $33 \pm 6$ \\
\hline
\end{tabular}

The IC50 of compound 5 for E. coli PBPIb was $59 \pm 3.3 \mu$ M. For comparison, the IC 50 value of moenomycin for $S$. aureus PBP2 was $1.3 \pm 0.3 \mu M$. 
Table 2. Susceptibility of a panel of bacteria to compounds 5, 5b and moenomycin.

\begin{tabular}{|c|c|c|c|}
\hline \multicolumn{4}{|c|}{$\mathrm{MIC}(\mu \mathrm{g} / \mathrm{ml})$} \\
\hline & 5 & $5 b$ & moenomycin \\
\hline E. faecalis ATCC 29212 & 16 & $4(10 \mu \mathrm{M})$ & $4(0.6 \mu \mathrm{M})$ \\
\hline L. innосиа АТСС 33090 & 8 & 4 & 4 \\
\hline S. aureus ATCC 25923 (MSSA) & 8 & 4 & 0.5 \\
\hline S. aureus ATCC 43300 (MRSA) & 8 & 4 & 0.5 \\
\hline S. aureus PL1 (MRSA) & 8 & 4 & 0.5 \\
\hline M. luteus ATCC 9341 & 8 & 4 & $>64$ \\
\hline S. epidermidis ATCC 12228 & 8 & 4 & 4 \\
\hline S. pneumoniae D39 & 16 & 4 & nd \\
\hline E.coli 1411 & 64 & 16 & nd \\
\hline E.coli $1411+\mathrm{PMBN}(4 \mu \mathrm{g} / \mathrm{ml})$ & 16 & 8 & nd \\
\hline E.coli SM1411 ( $\triangle a c r A B)$ & & 4 & nd \\
\hline Pseudomonas aeruginosa & 2 & $>250$ & nd \\
\hline
\end{tabular}

PMBN, polymyxin B nonapeptide. nd, not determined. 
Table 3. Induction of $B$. subtilis antibiotic biosensors in response to a panel of antimicrobial agents.

Upregulated biosynthetic pathway

\begin{tabular}{|c|c|c|c|c|c|}
\hline Antimicrobial Agent & Cell Wall & Protein & $R N A$ & $D N A$ & Fatty \\
\hline Vancomycin & + & - & - & & - \\
\hline Flucloxacillin & + & - & - & & - \\
\hline 5 or $5 b$ & + & - & & - & - \\
\hline Nisin & - & - & - & - & - \\
\hline Mersacidin & + & - & - & - & - \\
\hline Cetyltrimethylammonium bromide & - & - & - & - & - \\
\hline Tetracycline & - & + & - & - & - \\
\hline Anhydrotetracycline & - & + & - & - & - \\
\hline Fusidic Acid & 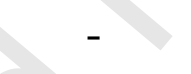 & + & - & - & - \\
\hline Rifampicin & - & - & + & - & - \\
\hline Rifamycin SV & - & - & + & - & - \\
\hline Ciprofloxacin & - & - & - & + & - \\
\hline Trimethoprim & - & - & - & + & - \\
\hline Triclosan & - & - & - & - & + \\
\hline
\end{tabular}

+/- Induced/uninduced biosensor in response to a range of concentrations of antimicrobial agent $(0.005-20 \mu \mathrm{g} / \mathrm{ml})$. 


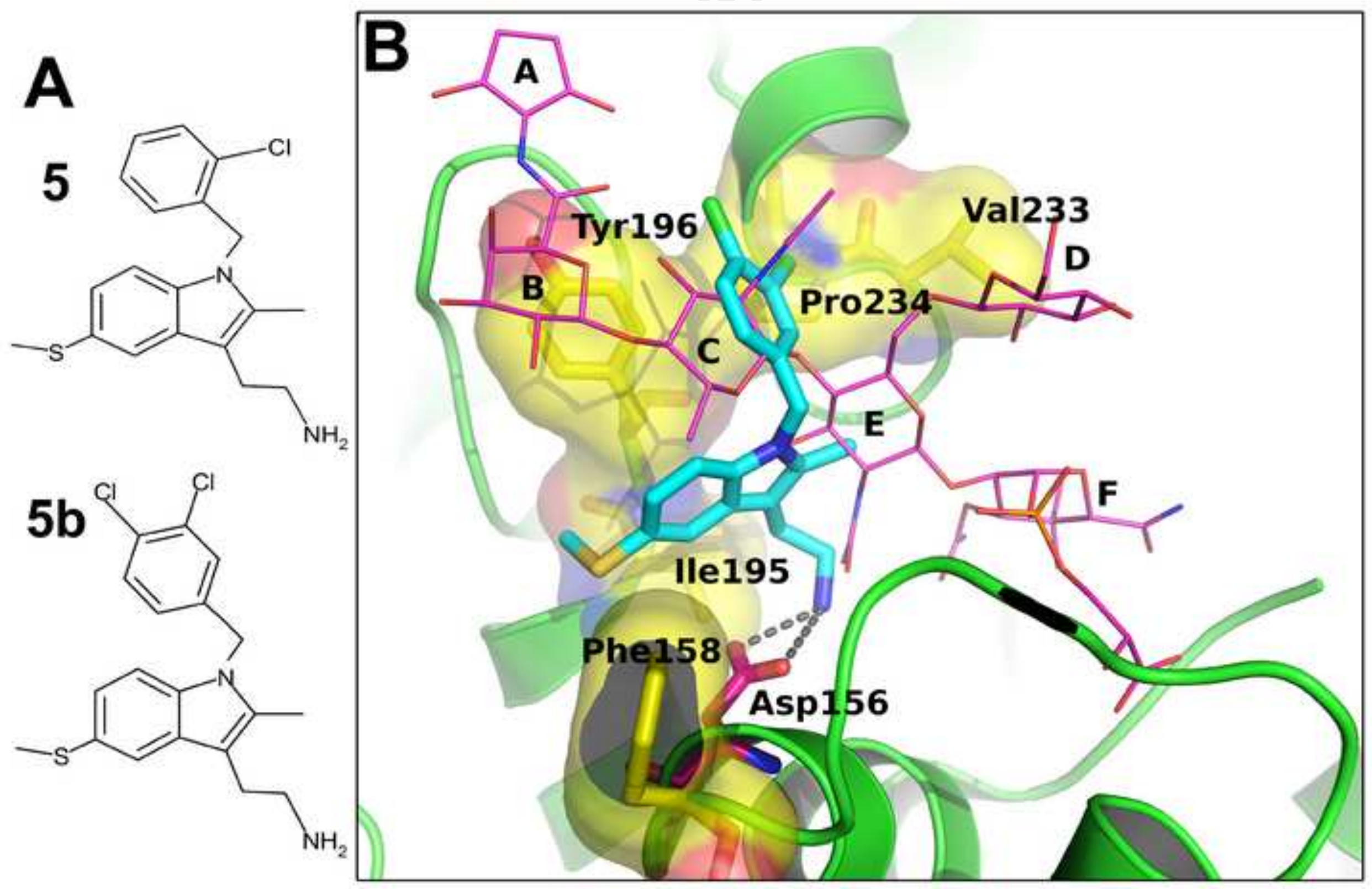

A

\section{Asp156}


Click here to download high resolution image

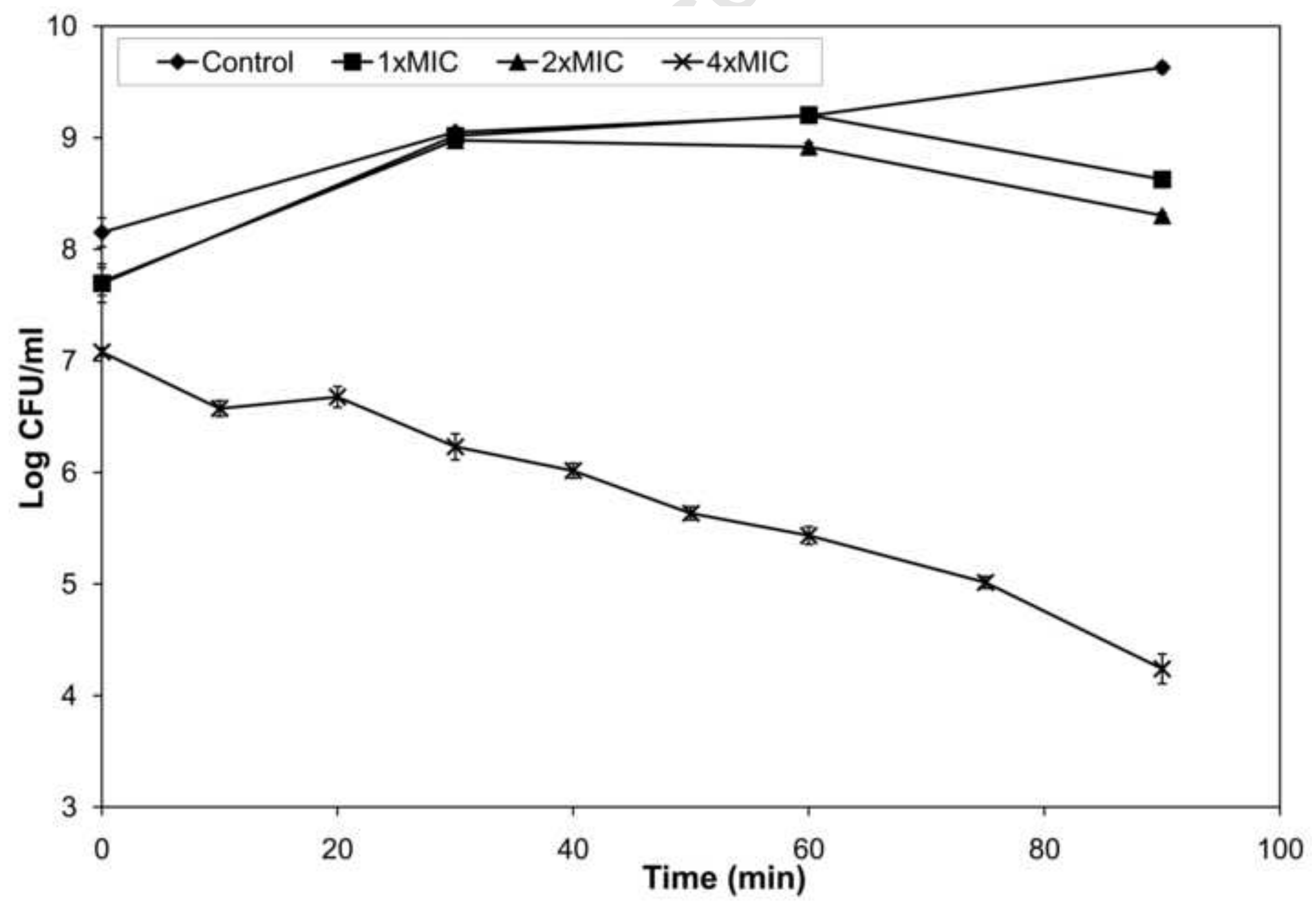



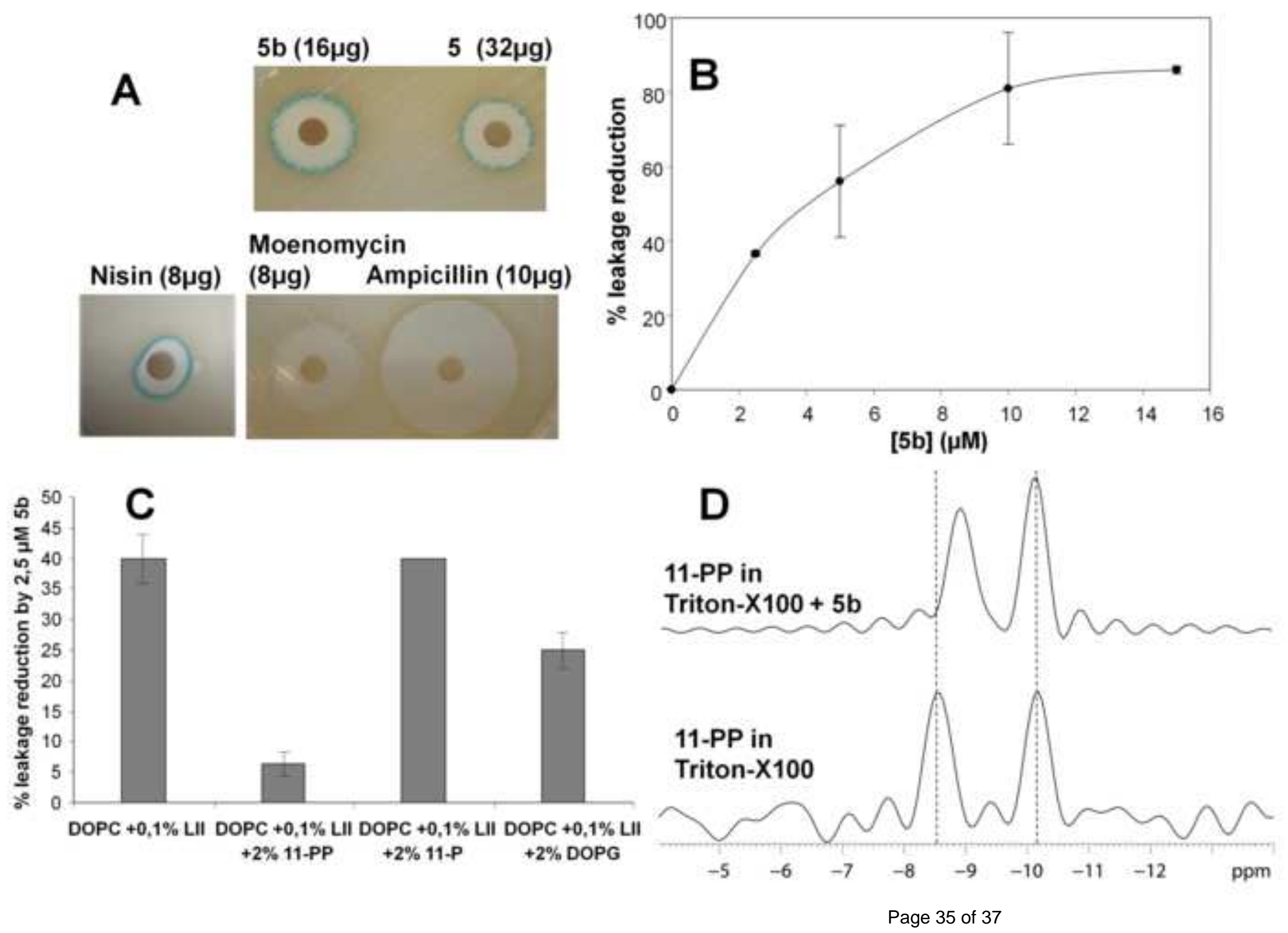
Click here to download high resolution image
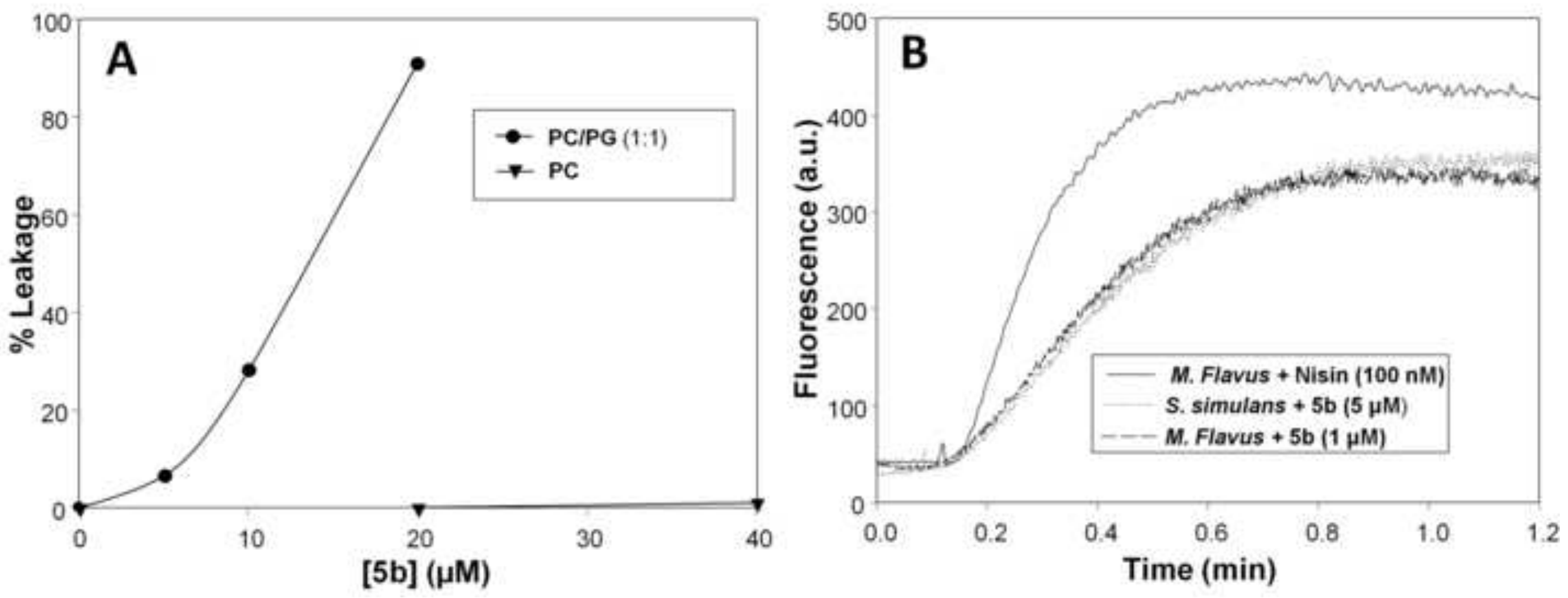


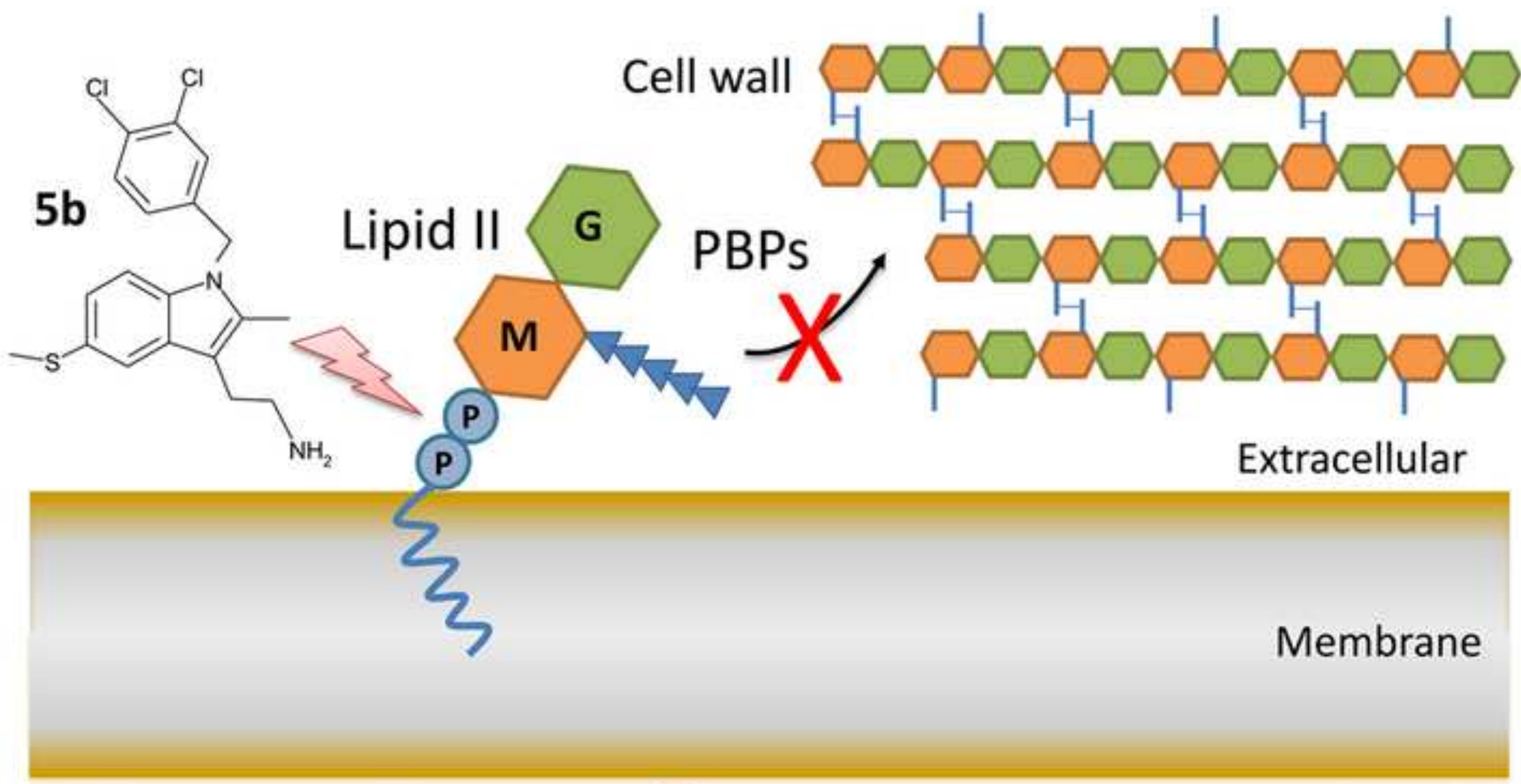

(M) MurNAC

G GICNAC

(P) Phosphate

Cytosol 